\title{
Parental care for infants with feeding tube: psychosocial repercussions
}

\author{
O cuidado prestado por pais a lactentes com sonda alimentadora: repercussões psicossociais \\ Cuidado de los padres para lactantes con sondas de alimentación: repercusiones psicosociales
}

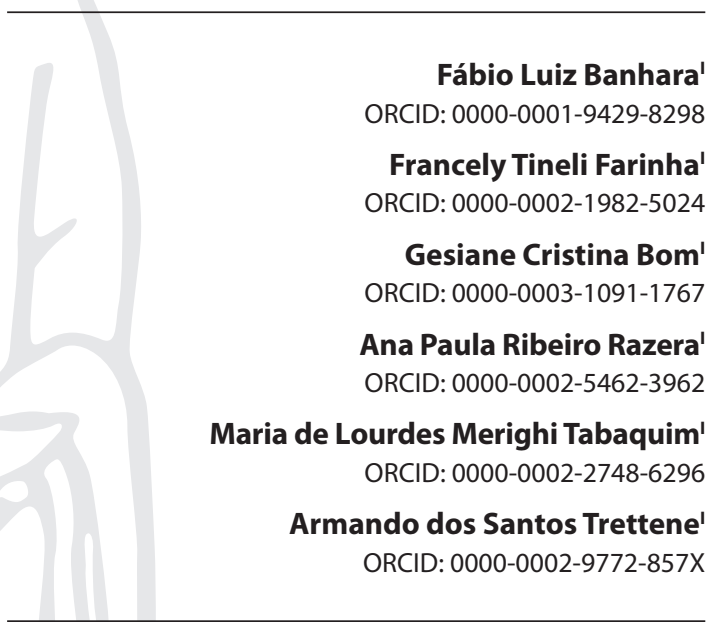

'Universidade de São Paulo, Hospital de Reabilitação de Anomalias Craniofaciais. Bauru, São Paulo, Brazil.

How to cite this article:

Banhara FL, Farinha FT, Bom CG, Razera APR, Tabaquim MLM, Trettene AS. Parental care for infants with feeding tube: psychosocial repercussions. Rev Bras Enferm. 2020;73(2):e20180360. doi: http://dx.doi.org/10.1590/0034-7167-2018-0360

Corresponding Author: Armando dos Santos Trettene

E-mail: armandotrettene@usp.br

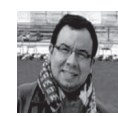

EDITOR IN CHIEF: Antonio José de Almeida Filho ASSOCIATE EDITOR: Priscilla Broca

Submission: 05-25-2018

Approval: 09-29-2018

\begin{abstract}
Objectives: to understand the psychosocial repercussions experienced by caregiving parents, resulting from care for the child with dysphagic cleft lip and palate. Methods: qualitative study, developed in a tertiary hospital in September 2016. The sample defined by theoretical saturation consisted of seven mothers. Data collection was performed by unstructured interview, being audio-recorded and fully transcribed. Symbolic Interactionism was used as theoretical framework, and Thematic Content Analysis as methodological framework. Results: the following themes emerged: diagnosis impact and coping; coping with overload and stress; interaction between caregivers as an acceptance and coping strategy; impact on family and social life of caregivers; and curiosity coping, and family and community prejudice. Final considerations: despite the physical and emotional overload, the mother figure plays the main and determining role in care, reflecting the complexity of care. Descriptors: Deglutition Disorders; Family Relations; Cleft Lip; Cleft Palate; Caregivers.
\end{abstract}

\section{RESUMO}

Objetivos: compreender as repercussões psicossociais vivenciadas por pais cuidadores, decorrentes do cuidado do filho com fissura labiopalatina, disfágico e em uso de sonda alimentadora. Métodos: estudo qualitativo, desenvolvido em um hospital terciário em setembro de 2016. A amostra definida por saturação teórica constou sete mães. A coleta de dados foi realizada por entrevista não estruturada, audiogravada e transcrita na íntegra. Utilizou-se como referencial teórico o Interacionismo Simbólico e como referencial metodológico, a Análise de Conteúdo Temática. Resultados: foram elucidadas cinco categorias: impacto e enfrentamento do diagnóstico; enfrentamento da sobrecarga e o estresse; interação entre cuidadores como estratégia de aceitação e enfrentamento; impacto no convívio familiar e social dos cuidadores; e enfrentamento da curiosidade e o preconceito familiar e comunitário. Considerações finais: apesar da sobrecarga física e emocional, a figura materna exerce o papel principal e determinante no cuidado, refletindo a complexidade do processo de cuidar.

Descritores: Transtornos da Deglutição; Relações Familiares; Fenda Labial; Fissura Palatina; Cuidadores.

\section{RESUMEN}

Objetivos: comprender las repercusiones psicosociales experimentadas por los padres cuidadores, como resultado del cuidado del niño con labio leporino y paladar hendido disfagico. Métodos: estudio cualitativo, desarrollado en un hospital terciario en septiembre de 2016. La muestra definida por saturación teórica consistió en siete madres. La recopilación de datos se realizó mediante entrevista no estructurada, grabada en audio y totalmente transcrita. Se utilizó como referencia teórica el interaccionismo simbólico y como referencia metodológica, el análisis de contenido temático. Resultados: se aclararon cinco categorías: impacto y afrontamiento del diagnóstico; hacer frente a la sobrecarga y el estrés; interacción entre cuidadores como una estrategia de aceptación y afrontamiento; impacto en la vida familiar y social de los cuidadores; y afrontamiento de curiosidad y prejuicio familiar y comunitario. Consideraciones finales: a pesar de la sobrecarga física y emocional, la figura materna desempeña el papel principal y determinante en la atención, lo que refleja la complejidad del proceso de lo cuidado.

Descriptores: Trastornos de la Deglución; Relaciones Familiares; Labio Leporino; Paladar Hendido; Cuidadores. 


\section{INTRODUCTION}

Cleft lip and palate are among the most common craniofacial malformations, and may affect alone or in association with the lip, alveolar ridge, and palate. The incidence is 1: 650 live births. The etiology is multifactorial and included genetic and environmental factors. There may be functional, aesthetic and psychosocial problems ${ }^{(1-2)}$.

About $30 \%$ to $50 \%$ of patients with cleft lip and palate present other malformations or associated syndromes. In these cases in particular, functional problems are more intense, including food problems ${ }^{(2)}$. Thus, the concern with food occupies a prominent place among parents and caregivers, manifesting soon after the diagnosis of cleft lip and palate, even when intrauterine ${ }^{(3)}$.

Children with isolated cleft lip and palate usually have transient eating problems associated with ineffective suction, poor lip sealing, food reflux, and choking. These, through interventions guided by qualified professionals and referral centers, have a very favorable prognosis. They have age-appropriate growth and development, although they need to be monitored for weight gain ${ }^{(4)}$.

In contrast, in cases associated with syndromes and other malformations, functional impairment, particularly eating, is concerning. Thus, these children may develop oropharyngeal dysphagia and often use feeding tubes ${ }^{(5)}$.

Dysphagia is a disorder that makes it difficult to safely, efficiently and comfortably ingest any food or saliva. They can be divided into oropharyngeal or high, and esophageal or low. Oropharyngeal can be classified as mild, moderate and severe according to the degree of food penetration in the laryngeal region, history of recurrent pneumonia and decreased eating pleasure ${ }^{(6)}$.

Feeding tube use does not contraindicate discharge. However, informal parents or caregivers should be trained to ensure continuity of care at home after hospital discharg $\mathrm{e}^{(5,7)}$.

Care for a dysphagia child using a feeding tube includes continual supine positioning, diet preparation and administration, maintenance of tube permeability, proper tube fixation, nasal and oral hygiene, and monitoring of complications (nausea, vomiting, diarrhea, stacking, reflux, among others). This care requires vigilance and dedication, which added to the inherent care of the infant can generate stress and overload for caregivers ${ }^{(5,7)}$.

Delay in the therapeutic definition associated with prolonged length of stay and the need to travel to specialized centers is a costly condition for family members. In addition, it can directly impact personal aspects, family and social dynamics. Lack of knowledge about the course of pathology, as well as beliefs about the moral duty of family members to provide care, particularly of parents, is reluctant or difficult to ask for support. As consequence, there is social isolation, which may cause caregiver loneliness and depression ${ }^{(8)}$.

Associated with feeding difficulties, the figure of the malformed child collapses the narcissistic fantasy of perfection, revealing limitations and the feeling of inability to produce a healthy baby, making it difficult for parents to accept it. At this point, parents need to discard the image created during pregnancy and begin the process of adjusting the actual baby, oscillating between the experience of personal growth and feelings of mourning for the loss of the idealized child ${ }^{(8)}$.
Parental care takes on dramatic contours because of its chronic character. Thus, parents experience conflicting feelings, such as despair and fear. Care is associated with decreased quality of life and health deterioration, especially in cases of chronicity and greater dependence on the patient or family receiving care ${ }^{(9)}$.

The following question emerged: what are the meanings and senses attributed by caregiver parents regarding psychosocial implications they experience, resulting from care for their children with dysphagia using a feeding tube?

Although studies on dysphagia children are available, those referring to the universe of social implications experienced by caregiver parents are incipient. The success of the rehabilitation process and the quality of care provided depend greatly on caregivers' physical, emotional and psychosocial health. Therefore, these reasons justify the development of this investigation.

\section{OBJECTIVES}

This study aims to understand the psychosocial repercussions experienced by caregiving parents, resulting from care for the child with cleft lip, dysphagia, and feeding tube.

\section{METHODS}

\section{Ethical aspects}

The research was carried out after approval by the Hospital's Research Ethics Committee. Participants formalized adherence by signing the Informed Consent Form and all ethical precepts were observed.

To identify the speech and ensure participant anonymity, letter " $C$ " (caregiver) was used for each subject, as well as sequential Arabic numbers.

\section{Theoretical-methodological framework}

Symbolic Interactionism was used as a theoretical framework. The definition of the experienced situation is central to direct the action, since they are caused by an active decision-making process by the individual, as well as interaction with oneself and others. It comprises five central ideas, including: the role of social interaction, thinking, definition, present, and active human being. In short, from the establishment of meanings, there are actions. Thus, the individual interacting influences his actions. In this sense, every phenomenon needs to be grasped and understood from the perspective of the living ${ }^{(10)}$.

Thematic Content Analysis was used as a methodological framework. This framework consists of a discourse analysis technique aiming at understanding them, where themes, categories and subcategories are subtracted, that is, it allows us to discover the core of meaning that make up a communication ${ }^{(11)}$.

\section{Type of study}

This is a descriptive study with a qualitative approach. Qualitative research seeks to work with the universe of meanings, motives, beliefs and values as part of the social reality of individuals ${ }^{(11-12)}$. 
Parental care for infants with feeding tube: psychosocial repercussions Banhara FL, Farinha FT, Bom CG, Razera APR, Tabaquim MLM, Trettene AS.

\section{Study setting}

The present investigation was developed in a public, tertiary referral hospital for caring for patients with craniofacial anomalies and related syndromes, located in the countryside of the city of São Paulo, Brazil. It has 91 beds and is managed with resources from the University of São Paulo and the Brazilian Unified Health System (Sistema Único de Saúde).

The semi-intensive hospital unit was contemplated in the present study. It consists of eight beds for newborns to children up to two years old who often had respiratory and eating problems. In addition, parents and/or informal caregivers remain during the daytime to receive childcare training to maintain at home after discharge.

\section{Methodological procedures}

The intentional and convenience sample was defined by theoretical saturation ${ }^{(11-12)}$ that happened in the seventh interview, that is, seven caring mothers participated. Inclusion criteria included: being a responsible parent or caregiver of infants using a feeding tube for more than 30 days and who had already been discharged from hospital.

For data collection, unstructured interview and the following questions were used: how has it been for you to take care of a child who uses a tube to feed? What were the main changes in your daily activities after you started taking care of your child? What are your biggest difficulties in taking care of your child? Do you feel supported?

Interviews took place privately, during the hospitalization of infants, at a time pertinent to their parents, and were recorded on a digital audio device. After each interview, the content of the recordings was fully transcribed in order to facilitate the process of analysis of emerging data, in addition to improving and deepening the subsequent interview ${ }^{(11-12)}$.

The average duration of the interview was 40 minutes. Data analysis took place concurrently with the interviews, aiming to identify when the speeches became recurrent ${ }^{(12)}$.

It is noteworthy that the researchers did not have direct contact with the participants nor with the infants during hospitalization, since they did not work in the unit where they were hospitalized.

Participants were characterized according to age, gender, marital status, number of children, education and socioeconomic classification $^{(13)}$. Data collection took place in September 2016.

\section{Data analysis}

Result treatment was performed by the inference and interpretation of the contents by categories and similarity. It followed the Thematic Content Analysis methodology, which was systematized in the following phases: pre-analysis - there was a fluctuating reading of the interview contents through the principles of completeness, representativeness, homogeneity and relevance; material exploration - coding operations were constructed through the identification of keywords and related themes, with subsequent aggregation information aggregation into thematic categories; interpretation - there was result treatment, inference and interpretation, supported by Symbolic Interactionism ${ }^{(10-12)}$.

\section{RESULTS}

Seven mothers, aged between 20 and 35 years old, participated in this study. Prevailed to married, belonging to the low social class and with incomplete high school.

From content analysis, five categories emerged: diagnosis impact and coping; overload and stress coping; interaction among caregivers as an acceptance and coping strategy; impact on caregivers' family and social life; and curiosity coping, and family and community prejudice.

The category "diagnosis impact and coping" was characterized by a wide range of feelings that included: fright, insecurity, fear, worry and discredit, as reported below:

It was very scary at first, I was very insecure...I was afraid to take home with the tube...I was shook because my other children were all born perfect...they ate with their mouth. (C1)

It was hard to believe...it was very traumatic...it is a very bad feeling she could not feed by mouth... to my husband it was like losing the floor. (C3)

Scared because you have to be very careful, besides the worry of going wrong, the tube...brings suffering to us. (C6)

In addition to the unveiled feelings, there was the frustration or disappointment that they could not breastfeed their children, according to the following reports:

I was sad because it was my dream to breastfeed, and I couldn't... frustration...but I milked breast milk and they passed the tube. (C4)

It hurts so much not being able to breastfeed, it's disappointing... (C2)

My dream has always been to breastfeed my child, but because of the dysphagia, I couldn't breastfeed him. (C5)

Although negative feelings and unpleasant feelings were made explicit, the finding of benefits promoted awareness of the need to use the tube, resulting in coping mode, as explained in the following speeches:

At first it was very difficult, but then we feel a huge relief because you see weight gain and she doesn't cry from hunger. (C2)

Then I saw that it would be best for her...my husband and I...only brought benefits to him to this day. (C5)

In the beginning it was hard. I spent almost a month getting real, but then it was quiet. I understood that it was for his good and that it was necessary. (C4)

"Overload and stress coping" was unveiled from the speeches, where caregivers sought to report the difficulties regarding the psychological and subjective aspects of care. Most of them reported having experienced, at some point, a high level of stress and feeling of overload related to the burden imposed by care for the child with the feeding tube, plus care for the home, other children, spouse, among others. However, faith in 
Parental care for infants with feeding tube: psychosocial repercussions Banhara FL, Farinha FT, Bom CG, Razera APR, Tabaquim MLM, Trettene AS.

God was observed as a coping strategy. The following speeches exemplify this category:

At first, I felt a huge burden, and it was very difficult...besides taking care of the son, he takes care of the house, the other children, the husband. It gives a fatigue more psychological than physical. (C2)

I felt overwhelmed especially at first because it was just me before. I've cried too much; I've thought of giving up...then I prayed to God. But I will not give up. (C3)

I feel very, very overwhelmed because you have to stay on top of her and there are more boys, you get tired a lot. But I turn to God and keep moving on. (C6)

Overload and stress were mainly related to the fact that mothers take over as the main caregivers, either because they do not receive support from their spouse or family, or because they do not trust care provided by others.

I take care of myself, day and night. It's difficult. From my family I only have my niece, I've already lost my mother, my father, I've lost everyone...it's hard...I get exhausted. (C5)

Nobody helps me. I take care myself. My husband helps give others a bottle, but tampering with the tube does not...he thinks she suffers because of the tube...people are afraid to care for. (C6)

Only I take care, there's nobody to help me ... only my mother-inlaw who helps me from time to time. But she doesn't touch the tube, just me. I have no confidence in letting someone else take care, I prefer do it myself. (C7)

Another listed category referred to "interaction among caregivers as a coping strategy". The benefits from the exchange of experiences and information among caregivers were identified, which contributed to reinforce trust and promote coping strategies. The following speeches exemplify:

More experienced mothers always help and reassure those who are coming. I learn a lot from them...there are even whatsapp groups where they ask questions and exchange experiences. (C2)

The contact with the mothers facing the same problem was very good...I made friends with many of them... when I had doubts, I asked them, and they answered me. It was a support. (C4)

I was talking to moms and getting more confidence. (C6)

Another category that emerged from the speeches referred to the "impact on caregivers' family and social life". It involved restriction in the home environment and in receiving visits, related to the child's fear of acquiring infections; need to leave the employment relationship even contradicted, prioritizing child care; impact on marital relationship demonstrated by fear of having other children with the same difficulty and by spouse's attention. The following discourses exemplify this category:

I changed my routine a lot. I did not go out anymore and do not receive visits, because of his care and our concern, not because of shame. (C1)
Istopped doing a lot of things now that I started going out with her ... not out of shame! Only my husband and I are afraid of having another child and happening all over again. (C4)

My husband thinks I have time just for her, I don't spend any time for him ... he usually asks for a little more attention on things, because I have attention only to her little things ... he asks me for attention a lot ... I had I want to quit my job to take care of him. I wouldn't like it, but it's the priority. (C7)

When contextualizing about caregivers' experiences, "curiosity and family coping, and community prejudice" emerged. It was revealed from the discontent of caregivers about the excess of questions on the child's condition either by population or family. It was noticed in some cases that the questions were interpreted as a form of curiosity, not prejudice. In contrast, other caregivers identify a veiled prejudice. Caregivers, seeking to avoid embarrassment, often isolate themselves in their home contexts. The following speeches are examples:

I just go out with him to the doctor. To people, it looks like he's an ET. People stare and wonder what it is...snooping...they're very curious...they treat her as disabled. (C1)

It has a hidden prejudice, in disguise. This is ignorance, lack of knowledge. I want you to treat my daughter like a normal child, because she is a normal child. (C3)

There is a lot of prejudice, as people from my city...some people who came to ask was more curiosity to know and then spreading out... there are many people to criticize you and find it monstrous. (C4)

\section{DISCUSSION}

The present study showed the maternal figure as the main caregiver. This result reflects mothers' understanding of their moral obligation to provide care, which is often interpreted as an obligation. Different studies presented mothers as main caregivers ${ }^{(7,14-15)}$.

Delegating care to women has historical and sociological bases, originated in the division of functions and definition of roles influenced by biopsychological factors, such as the fact that it generates and feeds the baby, and, predominantly, by cultural factors resulting from the patriarchal view of women as responsible. for the home and care. In contrast, man is identified as the provider of material resources ${ }^{(15)}$.

Women, in addition to performing activities related to motherhood, have several other activities including paid, home care and management, care for other children and spouse, as well as self-care. These factors in association may contribute to increased stress and overload and may cause physical and/or psychological changes, in accordance with those found in this investigation ${ }^{(16)}$.

In the category that addressed diagnosis impact, attitudes towards the experience of caring for the child with dysphagia were explained. They were characterized by a varying range of feelings and reactions that included fright, insecurity, fear, worry, discredit, sadness, and frustration at being unable to breastfeed, and difficulty accepting reality. However, later, from the realization of benefits by using the feeding tube, coping was realized. It was unveiled, therefore, that the actions of individuals are developed 
according to interactions among people, who interpret and define situations, act in the context where they are inserted ${ }^{(10)}$.

This study pointed out that the parents'feeling of unpreparedness and inexperience regarding the situation experienced, as well as visualization of health professionals' misunderstanding with their needs. It resulted in greater contact with other parents to exchange experiences, which evidenced a type of coping ${ }^{(17)}$.

Relationships with other parents represent important support, where informal opportunity to observe the behavior and reactions of other families experiencing similar experiences makes it possible to identify each other's problems. Thus, it is attributed a positive meaning to perceive in the doubt of others, acquires a sense of belonging and not isolation in the diagnostic condition, not being unique to experience this situation. In addition, parents with more reserved or insecure attitudes may feel more empowered by sharing and supporting each other with a similar state $^{(18-19)}$.

The fact that the child does not fit the normality standards leads the family members to great surprise and shock due to the contact with the new, feelings of guilt and fear due to the lack of knowledge about the pathology and concern about the future ${ }^{(20-21)}$.

Parents are the first references in the formation of the child's personality and responsible for providing conditions for the child to be understood by society in his special condition of being. Culturally, people expect and plan a child. From the beginning, they dream of the best for him from pregnancy and birth, turning into an apprehensive and anxious wait. However, in some cases this dream turns out to be different from the idealized one, frustrated in its intimacy and towards society ${ }^{(22)}$.

Feeding tube use is related, by caregivers and family members, to risk of death and complications, fear of pain, discomfort and the unknown. However, after the realization of the benefits of this therapy, especially in the evidence of its contribution to adequate weight gain, negative reactions and feelings are minimized or remedied. The present investigation pointed out the caregivers' anguish about the need to interrupt oral feeding, caused mainly by frequent hospitalizations, illnesses and weak sucking reflex. It negatively impacts caregivers' quality of life ${ }^{(17)}$.

Psychic suffering impact, felt by the child's vulnerability, passive in her sick condition, disrupts the whole family daily life, redirecting the time spent in care and broadening caregivers' responsibilities. From the negative and positive experiences attributed by the caregiver, they experience a threshold of emotions determined by real or imaginary factors manifested by feelings, actions and thoughts. These emotions reflect the way they cope not only with the stressful situation of the moment, but their structural pattern of coping. Assim, o estresse pode ser mais avassalador em pessoas com maior vulnerabilidade diante de situações ameaçadoras, em virtude de vivências anteriores e características de personalidade ${ }^{(23)}$. Em suma, as pessoas são capazes de utilizar seu raciocínio e seu poder de simbolização para interpretar e adaptar-se flexivelmente às circunstâncias, a depender de como vivenciam a situação(10).

There is no doubt the need for interventions to promote the bond between mother and child, fostering the necessary attachment condition to ensure care and absence of neglect towards the baby. Breastfeeding interruption collapses the opportunity for greater mother/child binomial intimacy. In this sense, educational care aimed at mothers aiming at strengthening the bond and attachment becomes essential ${ }^{(24)}$.

From the reports of caregivers, it was found expression overload, linked to lonely care provision to for the child, in addition to the need for daily reorganization and restructuring. These factors, alone or in association, cause social isolation and abandonment of various activities, including employment, to ensure comprehensive child care ${ }^{(9,15)}$. Therefore, its subjective character is perceived. It cannot be translated as a personal attribute or an object in itself, but as a social product resulting from actioninteraction among those involved, which is manifested mainly in the way the individual feels the provision of care over time ${ }^{(10)}$.

High caregiver burden is associated with symptoms of stress, anxiety and depression to varying degrees. There is a consequent negative repercussion on the quality of life, in addition to negatively affecting care efficiency, which may lead to negligence or physical and psychological abuse ${ }^{(25-26)}$. Hence the importance of identifying risk factors and refer for clinical intervention.

Most caregivers in this study had a low level of education (incomplete high school). This factor may interfere with the search for information and access to better health care conditions because they do not have the knowledge about their rights and, consequently, do not seek to guarantee them. In contrast, higher education is related to higher perception of burden by caregivers, focusing on worsening perception of quality of life. However, the level of education influences the caregiver's personal view of their role. Thus, higher education, greater resources present in society and social participation tend to focus on improving the quality of care provided ${ }^{(18)}$.

In this investigation, it was revealed from the mothers reports about care implications of their children in their daily tasks, including caregivers' daily activities, increased costs leading to financial difficulties and stress on other family members. Added to this is the fact that most caregivers belong to the lower social class, therefore, with low incomes, besides being married and having more children. They need to divide personal time between home care, care for other family members, and the need to provide family income ${ }^{(14,20)}$.

Therefore, nursing care should cover not only the patient, but their caregivers, parents and family members, considering that care for dysphagic children using a feeding tube focuses on different contexts, including psychosocial care. In fact, it is observed that care for chronic and dependent patients, including infants using a feeding tube, negatively affects the health condition of caregivers, increasing morbidity and mortality in this population ${ }^{(25-27)}$.

Family support has been identified as a factor to reduce the burden and reduce the stress of caregivers, although care delivery has had a strong impact on the family requiring readjustment and routine changes with reduced work and leisure time. The family system senses this impact significantly, requiring restructuring ${ }^{(20,28)}$. In this context, it is revealed that the action is directed according to the goals and objectives that individuals determine as important ${ }^{(10)}$.

Family takes care of the resources they have and, in vulnerable situations, are exhausted due to prolongation or too much 
impact on the family system. From these situations crises and imbalances can be installed, generating family illness ${ }^{(29)}$.

Another context explained in the present study consisted of pointing out the interaction among caregivers as an acceptance and coping strategy. It is necessary to promote emotional support considering its influence on the quality of care provided to patients, since greater pressure on the caregiver is associated with lower quality of life for patients ${ }^{(16)}$.

In the present study, caregivers were between 20 and 35 years old, therefore young. This variable may be associated with lower social contact skills and less supportive social network, leading to increased social isolation and greater overload.

Social support is a coping tool in face of problems related to the situation of chronic illness, helping the subjects to have greater control of stressful situations. It is one of the variables that affect the family caregiver's quality of life and, consequently, the rehabilitation process. Lack of support leads to feelings of helplessness and insecurity ${ }^{(9,18)}$.

It can be seen, therefore, that human beings engage in a continuous stream of action that can be both open and hidden, whose actions result from the influence of social interaction. Thus, the direction of their lives will be based on positive or negative decisions ${ }^{(10)}$.

Another elucidated category of the speeches was related to the impact related to child care on the family and social life of caregivers. Caring for implies availability of time, requiring, in most cases, exclusivity. This reality directly affects the social, family and marital life of caregivers, negatively reflecting on their well-being and quality of life. In this context, there is often a need for family reorganization. Generally, care falls almost exclusively on the primary caregiver, full-time, leading him or her to leave home work. There is an impact on the family's financial condition, reducing their leisure opportunities and may have negative impacts on their affective relationships and social isolation ${ }^{(21)}$.

On the other hand, there are increasing existential transformations for the caregiver, which include the reframing of life based on a positive coping with changing the guidelines of their daily lives, emerging feelings of satisfaction and duty accomplished ${ }^{(25,30)}$.

Symbolic Interactionism enables the understanding of human social action, including the many decisions and choices that people make when acting in one way or another. Interaction is always important, because it leads the way ${ }^{(10)}$. Mothers, faced with the reality of caring for children with special needs, rethink their actions, giving meaning to what is really important for the moment.

In the context of marital relations, it can be configured as a support factor with development of greater intimacy or stress for the caregiver, through attitudes of recovery, as verified in the reports of caregivers. It was explained that the marital relationship can have a devastating effect and may be considered a stressor in some cases, or be identified as a strengthening factor for the caregiver ${ }^{(14,25)}$.

In fact, empathy becomes indispensable, as putting yourself in the other's shoes is essential to symbolic communication and self-development, and is considered one of the most important mental activities. This feature allows the individual, among others, to control and realize the consequences of their actions ${ }^{(10)}$. Therefore, it is possible to conceive the provision of care as a human action resulting from the actions and interactions of those involved.

The last category revealed in this study referred to curiosity and prejudice coping. It highlighted the difficulties of caregivers in dealing with situations regarding family and community, due to the fact that the child is fed by feeding tube, often causing social isolation at home.

In the face of the unknown, the natural human reaction of strangeness and revulsion about the new or the different is observed, being object of repudiation or pity. This differs from the standard considered normality and beauty by society, factors that are aggravated by pre-judgment and preconception, characterized by the lack of basis on information regarding the lived reality. Exposure to these situations contributes to the residence of both children and their caregivers, increasing social isolation ${ }^{(16)}$. Education is the key to a change in conception, respect for the notion of citizenship and a sense of sharing equal rights for all. In other words, we become social objects to each other through symbols, where we direct in favor of priorities, engage in actions that result in decision-making, redirect ourselves, share perspectives, and take on roles ${ }^{(10)}$.

It is possible to elucidate the process experienced by these parents, by assuming the responsibility of taking care of their children in a special situation. This occurs when using the feeding tube, whether seeking the knowledge necessary for care or seeking resources or support from family members and the community. If necessary, they should waive or underestimate issues related to their social and physical well-being ${ }^{(30)}$.

\section{Study limitations}

It is considered important to report that a single meeting or interview may not have been sufficient to capture the meanings and senses attributed by the participants and may characterize a limitation.

\section{Contributions to nursing}

The benefits of this study are evident, since the findings reflect care complexity that goes beyond care itself, reinforcing the need to insert caregivers in the context of nursing care. The results signed here reinforce the importance of family and community insertion as psychosocial support to caregivers.

\section{FINAL CONSIDERATIONS}

Notwithstanding the stressful and conflicting physical and emotional overload, with repercussions on family and social life, the mother figure plays the main and determining role in caring for the infant with dysphagic cleft lip and palate using a feeding tube.

Care complexity that goes beyond care itself, as well as the importance of family and community insertion as a psychosocial support to the caregiver, was noticed.

Health professionals from public and private institutions, including nursing, should include in care physical and mental well-being of informal caregivers monitoring. 
Care provided to children with cleft lip and palate should be shared with other family members, avoiding possible damage to the primary caregiver, such as overload, stress, and worse perception of quality of life.
Finally, elucidating the factors involved in the process of caring for these children by their informal caregivers can help in planning and implementing care and interventions, as well as providing guidance and follow-up strategies.

\section{REFERENCES}

1. François CF, Poli MLM, Nguyen P, Landais E, Gaillard D, Doco MF. Role of angiogenesis-related genes in cleft lip/palate: review of the literature. Int J Pediatr Otorhinolaryngol [Internet]. 2014 [cited 2017 Sep 09];78(10):1579-85. Available from: http://www.ijporlonline.com/ article/S0165-5876(14)00445-5/fulltext.

2. Freitas JAS, Almeida ALPF, Soares S, Neves LT, Garib DG, Trindade IKS, et al. Rehabilitative treatment of cleft lip and palate: experience of the Hospital for Rehabilitation of Craniofacial Anomalies/USP (HRAC/USP) - Part 4: Oral Rehabilitation. J Appl Oral Sci [Internet]. 2013 [cited 2017 Sep 09];2013;21(3):284-92. Available from: http://www.scielo.br/pdf/jaos/v21n3/1678-7757-jaos-21-03-284.pdf

3. Lindberg N, Berglund AL. Mothers' experiences of feeding babies born with cleft lip and palate. Scand J Caring Sci. 2014;28(1):66-73. doi: $10.1111 /$ scs.12048 doi: $10.1111 /$ scs. 12048

4. Martin V, Greatrex SW. An evaluation of factors influencing feeding in babies with a cleft palate with and without a cleft lip. J Child Health Care [Internet]. 2014 Mar [cited 2017 Oct 27];18(1):72-8. Available from: http://journals.sagepub.com/doi/pdf/10.1177/1367493512473853

5. Trettene AS, Luiz AG, Razera APR, Maximiano TO, Cintra FMRN, Monteiro LM. Nursing workload in specialized Semi-intensive Therapy Unit: work force size criteria. Rev Esc Enferm USP. 2015;49(6):960-6. doi: 10.1590/S0080-623420150000600012

6. Furkim AM, Nascimento Jr JR. Gestão e gerenciamento em disfagia orofaríngea. In: Marchesan IQ, Silva HJ. Tratado das especialidades em Fonoaudiologia. São Paulo (SP): Guanabara Koogan; 2014. p. 55-69.

7. Trettene AS, Fontes CMB, Razera APR, Gomide MR. Impact of promoting self-care in nursing workload. Rev Esc Enferm USP. 2016;50(4):633-9. doi: 10.1590/S0080-623420160000500014

8. Nidey N, Uribe LMM, Marazita MM, Wehby GL. Psychosocial wellbeing of parents of children with oral clefts. Child Care Health Dev [Internet]. 2016 Jan [cited 2018 Mar 12];42(1):42-50. Available from: http://onlinelibrary.wiley.com/doi/10.1111/cch.12276/epdf

9. Awoyale T, Onajole AT, Ogunnowo BE, Adeyemo WL, Wanyonyi KL, Butali A. Quality of life of family caregivers of children with orofacial clefts in Nigeria: a mixed methods study. Oral Dis. [Internet]. 2016 Mar [cited 2018 Mar 12];22(2):116-22. Available from: http://onlinelibrary.wiley. com/doi/10.1111/odi.12379/pdf

10. Charon JM. Symbolic Interacionism: an introduction, an interpretation, as integration. 10th ed. Boston: Prentice Hall; 2010.

11. Bardin L. Análise de conteúdo. São Paulo (SP): Edições 70; 2013.

12. Minayo MCS. O desafio do conhecimento: pesquisa qualitativa em saúde. 13a ed. São Paulo (SP): Hucitec; 2013.

13. Graciano MIG, Souza EG, Rosa JA, Blattner SHB. Validação de conteúdo de um instrumento de avaliação socioeconômica no âmbito do Serviço Social. Rev do Instituto de Pesquisas e Estudos: Construindo o Serviço Social [Internet]. 2015 [cited 2018 Mar 12];19(36):29-57. Available from: http://ojs.ite.edu.br/index.php/css/article/viewFile/214/253

14. Lefton MAG, Okelo SO, Wright JM, Collaço JM, McGrath SAM, Eakin MN. Impact of children's feeding/swallowing problems: validation of a new caregiver instrument. Dysphagia [Internet]. 2014 Aug [cited 2017 Aug 22]; 29(6):671-7. Available from: https://www.ncbi.nlm.nih.gov/ pmc/articles/PMC4359894/

15. Souza LR, Hanus JS, Libera LBD, Silva VM, Mangilli EM, Simões PW, et al. Sobrecarga no cuidado, estresse e impacto na qualidade de vida de cuidadores domiciliares assistidos na atenção básica. Cad Saúde Colet [Internet]. 2015 [cited 2017 Aug 15];23(2):140-9. Available from: http://www.scielo.br/pdf/cadsc/v23n2/1414-462X-cadsc-23-2-140.pdf

16. Trettene AST, Turbiani ACA, Razera APR, Souza NFH, Turbiani DGS, Souza JGS. Stress and overload in informative care of children with isolated Robin Sequence. Rev Enferm UFPE[Internet]. 2017[cited 2017 Aug 29];11(8):3013-20. Available from: http://www.revista.ufpe.br/ revistaenfermagem/index.php/revista/article/view/10326/pdf_3703

17. Nelson KE, Lacombe AD, Cohen E, Nicholas DB, Rosella LC, Guttmann A, et al. Family experiences with feeding tubes in neurologic impairment: a systematic review. Pediatr [Internet]. 2015[cited 2017 Sep 13];136(1):e140-151. Available from: http://pediatrics. aappublications.org/content/136/1/e140.long

18. Yamashita $\mathrm{CH}$, Amendola F, Gaspar JC, Alvarenga MRM, Oliveira MAC. Association between social support and the profiles of family caregivers of patients with disability and dependence. Rev Esc Enferm USP [Internet]. 2013 Dec [cited 2017 Sep 13];7(6):1357-64. Available from: http://www.scielo.br/pdf/reeusp/v47n6/en_0080-6234-reeusp-47-6-01359.pdf

19. Lopes LO, Cachioni M. Cuidadores familiares de idosos com doença de Alzheimer em uma intervenção psicoeducacional. Rev Bras Geriatr Gerontol. 2013;16(3):443-60. doi: 10.1590/S1809-98232013000300004

20. Figueiredo SV, Sousa ACC, Gomes ILV. Children with special health needs and family: implications for Nursing. Rev Bras Enferm [Internet]. 2016[cited 2017 Sep 13];69(1):79-85. Available from: http://www.scielo.br/pdf/reben/v69n1/en_0034-7167-reben-69-01-0088.pdf 
21. Silva TMV, Santos MA, Almeida FA. Understanding the experiences of caregivers of children with tuberculosis in directly observed therapy. Rev Esc Enferm USP [Internet]. 2014[cited 2017 Sep 13];48(Spe2):39-45. Available from: http://www.scielo.br/pdf/reeusp/v48nspe2/00806234-reeusp-48-nspe2-00039.pdf

22. Tabaquim MLM, Marquesini MAM. Study of the stress of parentes of patients with cleft lip and palate in a surgical process. Estud Psicol [Internet]. 2013[cited 2017 Sep 13];30(4):517-24. Available from: http://www.scielo.br/pdf/estpsi/v30n4/05.pdf

23. Joaquim RM, Tabaquim MLM, Valle TGM. Estratégias de enfrentamento e níveis de ansiedade de mulheres em tratamento psicológico. Arch Health Invest [Internet]. 2014 [cited 2017 Sep 13];3(3):39-57. Available from: http://www.archhealthinvestigation.com.br/ArcHI/article/view/691

24. Carmona EV, Vale IN, Ohara CVS, Abrão ACFV. Maternal perception regarding hospitalized newborns. Rev Bras Enferm [Internet]. 2014 [cited 2017 Sep 13];67(5):788-93. Available from: http://www.scielo.br/pdf/reben/v67n5/0034-7167-reben-67-05-0788.pdf

25. Manoel MF, Teston EF, Waidman MAP, Decesaro MN, Marcon SS. As relações familiares e o nível de sobrecarga do cuidador familiar. Esc Anna Nery Rev Enferm [Internet]. 2013 [cited 2017 Sep 13];17(2):346-53. Available from: http://www.scielo.br/pdf/ean/v17n2/v17n2a20.pdf

26. Medrano M, Rosario RL, Payano AN, Capellán NR. Burden, anxiety and depression in caregivers of Alzheimer patients in the Dominican Republic. Dement Neuropsychol [Internet]. 2014 [cited 2017 Oct 30];8(4):384-8. Available from: http://www.scielo.br/pdf/dn/v8n4/19805764-dn-08-04-00384.pdf

27. Parekh NK, Shah S, McMaster K, Speziale A, Yun L, Nguyen DL, et al. Effects of caregiver burden on quality of life and coping strategies utilized by caregivers of adult patients with inflammatory bowel disease. Ann Gastroentero [Internet]. 2017[cited 2017 Oct 30];30(1):89-95. Available from: https://www.ncbi.nlm.nih.gov/pmc/articles/PMC5198253/

28. Silveira A, Neves ET, Paula CC. Family care of children with special healtcare needs: a process of (super) natural care and (over) protection. Texto Contexto Enferm [Internet]. 2013 [cited 2017 Oct 30];22(4):1106-14. Available from: http://www.scielo.br/pdf/tce/v22n4/en_29.pdf

29. Bellato R, Araújo LFS, Dolina JV, Musquim CA, Corrêa GHLST. The family experience of care in chronic situation. Rev Esc Enferm USP [Internet]. 2016 [cited 2017 Oct 30];50(Spe):78-85. Available from: http://www.scielo.br/pdf/reeusp/v50nspe/0080-6234-reeusp-50-esp-0081.pdf

30. Razera APR, Trettene AS, Niquerito AV, Tabaquim MLM. Study of burden among caregivers of children with cleft lip and palate. Paidéia (Ribeirão Preto) [Internet]. 2017 Sep/Dec [cited 2018 Apr 27];27(68):3-10. Available from: http://www.scielo.br/pdf/paideia/v27n68/19824327-paideia-27-68-247.pdf 